\title{
ИНГИБИТОРЫ ФЕРМЕНТОВ РЕПАРАЦИИ ДНК НА ОСНОВЕ УСНИНОВОЙ КИСЛОТЫ
}

\section{А.С. Филимонов ${ }^{1}$, К.А. Орлова ${ }^{2,3}$, О.А. Лузина' ${ }^{1}$, Н.С. Дырхеева ${ }^{2}$, О.И. Лаврик², Н.Ф. Салахутдинов ${ }^{1}$}

${ }^{1}$ Новосибирский институт органической химии им. Н. Н. Ворожцова СО РАН, 630090, Россия, г. Новосибирск, пр-т ак. Лаврентьева, 9.

${ }^{2}$ Институт химической биологии и фундаментальной медицины СО РАН 630090, Россия, Новосибирск, пр-т ак. Лаврентьева, 8.

${ }^{3}$ Новосибирский государственный университет

630090, Россия, Новосибирск, ул. Пирогова, 1.

DOI: 10.19163/MedChemRussia2021-2021-301

E-mail: alfil@nioch.nsc.ru

Поиск ингибиторов ферментов системы репарации ДНК, относится к перспективным направлениям современной фармакологии и является одним из путей увеличения эффективности терапии онкологических заболеваний, особенно для борьбы с лекарственноустойчивыми опухолями. Разработка новых соединений, эффективно подавляющих активность различных ферментов репарации ДНК одновременно является непростой задачей. В данной работы была осуществлена попытка синтезировать дуальные или тройные ингибиторы нескольких перспективных ферментов-мишеней: тирозил-ДНК-фосфодиэстераз 1 и 2 (Tdp1 и Tdp2) и поли(АДФ-рибоза)полимеразы 1 (PARP1).

Природное соединение усниновая кислота 1 является широко распространённым вторичным метаболитом лишайников, химической трансформацией которой ранее были получены соединения, обладающие ингибирующей активностью по отношению к ферменту репарации Tdp1 [1].<smiles>CC(=O)C1=C(O)C=C2Oc3c(C(C)=O)c(O)c(C)c(O)c3[C@@]2(C)C1=O</smiles>

$\left({ }^{+}\right)^{- \text {usnic acid }}$

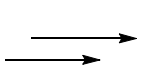

В данной работе нами были синтезирован ряд тиоэфиров усниновой кислоты 2, различающихся структурой заместителя у атома серы и была исследована их ингибирующая активность по отношению к ферментам репарации Tdp1, Tdp2 и PARP1. В ряду изученных соединений были выявлены как соединения, являющиеся селективными ингибиторами Tdp1, так и дуальные (Tdp1 и PARP1) и тройные ингибиторы (Tdp1, Tdp2 и PARP1). Установлено, что тип ингибирования Tdp1 для полученных соединений является бесконкурентным.

Работа была выполнена при поддержке РФФИ 19-415-540002

\section{References}

[1] A.L. Zakharenko et al. Eur. J. Med. Chem., 2019, 161, 581-93; A.S. Filimonov et al., Molecules. 2019, 24(20), 3711 